забезпечують своїм співом духовний спокій та відчуття піднесення під час служб в Свято-Троїцькому соборі. Керівник хору - талановитий митець, професіонал своєї справи успішно реалізує завжди вдало підібраний репертуар, швидко та якісно справляється 3 любими труднощами. Мабуть, саме тому хор «Оранта» $€$ завжди успішним та цікавим як для широкого загалу так і для спеціалістів мистецького кола.

\title{
Лiтература:
}

1. Марач О. М. Церковне хорове мистецтво Волині в добу державної Незалежності України. Украӥнська культура: минуле, сучасне, иляхи розвитку. Рівне. 2011. Вип. 17. С. 102-108.

2. Марач О. М. Академічне хорове мистецтво у соціокультурному континуумі західного регіону України періоду незалежності (на прикладі Волині): автореф. дис. ... канд. мистецтвознав. Львів, 2013. 17 с.

3. Тиможинський В. А., Шиманський П. Й., Новакович М. О., Єфіменко А. Г., Бернацька Г. О. Музичне мистецтво Волині XIX-XX століття: колективна монографія / за ред. П. Й. Шиманського. Луцьк: Твердиня, 2012. 168 с.

DOI https://doi.org/10.30525/978-9934-26-004-9-126

\section{ВОКАЛЬНА ТВОРЧІСТЬ СТАНІСЛАВА ЛЮДКЕВИЧА В КОНТЕКСТІ ЙОГО НАУКОВО-ПЕДАГОГІЧНОЇ ДІЯЛЬНОСТІ}

\author{
Михайлова О. Ю. \\ викладач вокалу II категоріі \\ Соиіально-гуманітарного управління виконавчого комітету \\ Комунального закладу «Богуславська школа мистецтв» \\ Богуславської міської ради Київської області \\ м. Богуслав, Київька область, Украӥна
}

Розбудова нашої незалежної держави неможливе без відродження національної культури, традицій українського народу, без піднесення його духовності й національної гідності. Серед усіх діячів музичної культури причетних до освіти та виховання молоді на національній основі значне місце належить Станіславу Людкевичу.

Життя та творчість С.П. Людкевича це приклад безкомпромісного служіння музиці, предметний урок композиторської та загальнолюдської етики. Безпосередне відношення композитора до музичного навчання та виховання дітей шкільного віку. Ще на початку XX ст. він визначив 
головні напрямки розвитку музичної освіти молодшого покоління, які мають гуманістичну спрямованість і не втратили своєї актуальності й сьогодні.

Щедрий талант композитора постійно живили, скріплювали цілющою водою такі джерела як зв'язок з народом, його історія, художньою творчістю, співучою мовою. Якого б жанру не торкався Людкевич у своїй діяльності, скрізь виявлявся неповторно індивідуаним, яскравим митцем. Висока музична культура, постійна жадоба навчання, напрочуд серйозне ставлення до творчих завданнь не могли не дати плідних результатів.

Створення композитором великих вокальних симфонічних полотен: кантата-симфонія «Кавказ», «Меланхолійний вальс», «Галицька рапсодія», «Рондо юнаків», симфонічні поеми: «Веснянки», «Каменярі», кантата «Заповіт» визначають магістральне русло його творчості.

Романси С. Людкевича відбивають істотні для його творчості художньо-стильові закономірності й поетичні уподобання, розкривають особливості музичного мислення митця.

У мистецькому доробку С. Людкевича є вокально-хорові твори яким належить особливе місце, твори досить різноманітні, тематико-образного та стильового діапазону: «Гамалія», «Поклик до братів-слов'ян», «Вічний революціонер», «Урочиста кантата», «Гей, слов'яни».

Представники Львівської композиторської школи, такі як: В. Барвінський, Р. Сімович, А. Солтис, М. Колесса, Е. Козак, А. КосАнатольський, Я. Ярославенко, Т. Маєрський, І. Винер, В. Флис, високо оцінили творчість С. Людкевича.

Особливо вабила композитора поезія Т. Шевченка та I. Франка як джерело майбутньої художньої сили, що спонукало засобами вокальносимфонічної музики відтворити образний стрій геніальних думок письменників, втілити ідеї героїчної боротьби народу за щастя і волю.

Маючи фундаментальну філологічну підготовку, Людкевич цікавиться проблемою взаємовпливів літератури й музики і як вчений виступив на «стиках» літературознавства й музикознавства. Результатом його роботи стала докторська дисертація «Дві проблеми розвитку звукозображальності» яку він захистив у 1908 році та дослідження «співності» поетичної спадщини Т.Г. Шевченка. Роздуми над творами українських і деяких російських композиторів до слів Тараса Шевченка, Людкевич продовжив у статті «Вокальна музика на тексти поезій «Кобзаря»«, які були написані на початку 30 -х років.

Найбільшу увагу С. Людкевич в своїх мистецько-критичних оцінках присвячує своєму метрові М. Лисенку. Також не обходе увагою видатний композитор своїх сучасників: К. Стеценка, Я. Степового, М. Леонтовича, В. Барвінського та інших. 
Викладацька діяльність С.П. Людкевича стала вагомим внеском у становленні національної педагогічної школи. Композитора турбує питання навчання музичного мистецтва в загальноосвітній школі, викладання музично-теоретичних предметів у спеціальних навчальних закладах. Для педагогічних принципів С. Людкевича характерне прагнення виховати справжнього професіонала і водночас громадянинапатріота.

Станіславу Людкевичу завжди була близькою концепція правди в житті і мистецтві. Педагогічне кредо композитора: «Музика і пісня як була, так і буде одним із головних чинників нашої культури». Тому спадщина композитора-педагога, Станіслава Людкевича, не втрачає своєї педагогічної цінності і сьогодні.

\title{
Література:
}

1. Антонович М. Станіслав Людкевич: композитор, музикознавець. Рим, 1980. 161 с.

2. Барвінський В. Митець великого обдарування // Мистецтво. 1958. № 4. C. 26-28.

3. Бабюк Л. Музично-педагогічна діяльність С. П. Людкевича // Творчість С.П. Людкевича. Збірник статтей. Київ, 1979. С. 47-51.

DOI https://doi.org/10.30525/978-9934-26-004-9-127

\section{ОМЕЛЯН НИЖАНКІВСЬКИЙ В АРХІВНИХ ДОКУМЕНТАХ ФОНДІВ СТРИЙСЬКОГО КРАЕЗНАВЧОГО МУЗЕЮ «ВЕРХОВИНА»}

\author{
Молчко У. Б. \\ доцент кафедри музикознавства та фортепіано \\ Навчально-наукового інституту музичного мистецтва \\ Дрогобицького державного педагогічного університету \\ імені Івана Франка \\ м. Дрогобич, Львівська область, Украӥна
}

Розвиток сучасної національної культури сьогодні невіддільний від вивчення творчих надбань митців, які в силу суспільно-історичних обставин початку XX століття змушені були емігрувати, покинути рідну землю. 3 цього приводу професор Ганна Карась наголошує, що «музична культура українців діаспори, як інтегральна частина загально- 